\title{
LLAMAMIENTO FRENTE A LA CRISIS DEL TERCER SECTOR
}

\section{Francisca Bernal Pérez.}

Enfermera Hospital de Bellvitge. Hospitalet de Llobregat. E-mail: paquibernal@gmx.es

Hemos topado con la horma de nuestra paciencia; si hasta hace unos meses nuestra Administración realizaba recortes en materia de salud en hospitales disminuyendo o suprimiendo intervenciones quirúrgicas no vitales, minando salarios a los profesionales y descartando servicios de ambulancias, amén de otras muchas tropelías. Ahora se han pasado al lado oscuro y se han cebado con los más débiles, aquellos que no se pueden defender: discapacitados y pacientes geriátricos. ¿Qué más tienen que hacer para darnos cuenta que las partidas presupuestarias del Estado se van hacia otra parte? Si no hay dinero para la Sanidad, no hay dinero para salvar a los bancos. Estamos empecinados en pensar que nuestros gobiernos nos van a sacar de esta crisis, pero nos hunden cada día más en la miseria. Somos los más pobres los que acarreamos con las consecuencias nefastas de esta vorágine de euros que nos engulle por completo en el más absoluto empobrecimiento.

Y no hay avistamientos de que esta situación se vaya a revertir en un período corto de tiempo; habrá más sufrimiento, más familias desesperadas para atender a los suyos, sin ayudas, sin convicciones morales y éticas de los que un día les prometieron un salvavidas y ahora les lanzan un yunque para que no puedan reflotarse.

Es indignante ver como se desmantelan todos los sectores sociales que amparaban a aquellas personas más indefensas sin importarles cómo les quede su situación personal. Este desamparo 
puede tener connotaciones de riesgo vital para estos pacientes, por lo que debemos denunciar todas las actuaciones negligentes que observemos.

Se precisa una unión de todos los colectivos sanitarios, una unión de todos los pacientes y sus familias para aunar esfuerzos para preservar nuestro Estado del Bienestar. No podemos quedarnos inertes ante un mancillamiento constante de nuestros derechos fundamentales. Si bien es cierto que nuestro Gobierno refiere que no hay dinero en nuestras arcas, es también cierto que todavía a día de hoy imperan gastos cuantiosos en actuaciones irrelevantes que propician más recortes a los más débiles. No son necesarios hoy por hoy tanto gasto superfluo, las políticas sociales deben ir dirigidas a los que por sus condiciones psíquicas y físicas necesiten de ese amparo legal que nuestra Constitución dirime que lo tiene. Hagamos oír sus voces en todos los estamentos, hagamos oír nuestras voces ante unos políticos ávidos de resguardar sus asientos en la comodidad de un gran salón al que denominan Parlamento y está tan lejos del Pueblo como de sus propios discursos inoperantes y caducos. Hagamos plantear al Gobierno una duda existencial: La movilización de las masas atempera la autoridad y hace que se replanteen muchas ideologías perennes en el tiempo. No son días de luchar en contra de los colectivos sociales y sanitarios, no es hora de iniciar pugnas desacreditativas en contra de los trabajadores de la salud, es hora de incitar a una rebelión de palabras y derechos que son nuestros, por imperativo legal.

Si en unos principios de la crisis, fuimos los funcionarios, después los pacientes, después los desempleados, los encargados de sufrir las puntillas presupuestarias, no podemos dejar ahora que las personas que no se puedan defender caigan en las hordas de personajes que no priorizan las realidades sociales más importantes. Y cuando digo que no priorizan las realidades, me refiero que hay muchas partidas donde equilibrar los presupuestos sin mancillar los derechos de los que sí los tienen por Imperativo legal y social.

Dejémonos de burdas reyertas entre el Pueblo y ahondemos en el fondo de la cuestión, no nos quedemos con andróminas y mantengamos un pulso al Gobierno. Cuando la masa se une no se fraccionan las fuerzas, sino que aumentan y este aumento genera reflexiones en nuestros políticos. Pues hagamos que estas reflexiones aunque tardías inicien tiempos de maduración en cuanto a los poderes sociales y sus logros futuros. 